\title{
HUBUNGAN DUKUNGAN KELUARGA DAN PEMBERIAN ASI DENGAN STATUS GIZI BAYI 0-6 BULAN DI WILAYAH KERJA PUSKESMAS PEUKAN BADA ACEH BESAR
}

\author{
Relationship Of Family Support And Association With Baby Nutrition Status 0-6 \\ Months In The Working Area Of Pukkmas Peukan Besar Aceh Bada \\ Syarifah Asyura *1, Novi yanti \\ Koresponding email : syarifah a@uui.ac.id*1 \\ Universitas Ubudiyah Indonesia
}

\begin{abstract}
Abstrak
Kekurangan asupan gizi pada masa bayi dapat menimbulkan kerusakan otak, letargi, sakit, dan penurunan pertumbuhan fisik. Status gizi dapat ditingkatkan dengan pemberian ASI secara optimal dan dengan adanya dukungan keluarga Dari data Puskesmas Peukan Bada tahun 2016 yang mencakup 27 desa di dapatkan 2 balita $(0,04 \%)$ berstatus gizi buruk, 144 balita $(28,8 \%)$ berstatus gizi kurang, dan 354 balita $(70,8 \%)$ berstatus gizi baik. Untuk mengetahui Hubungan Dukungan Keluarga dan Pemberian ASI dengan Status Gizi Bayi 0-6 Bulan di wilayah kerja Puskesmas Peukan Bada Aceh Besar. Jenis penelitian bersifat analitik dengan pendekatan crossectional yang dilakukan wilayah kerja Puskesmas Peukan Bada Aceh Besar pada tanggal 15 Maret - 29 April 2017. Jumlah sampel dalam penelitian ini sebanyak 67 orang dengan teknik stratified random sampling,. Pengumpulan data menggunakan kuesioner dan uji statistik menggunakan chi-square. Berdasarkan hasil uji statistik, dari 27 responden yang mendapat dukungan dari keluarga status gizi balita mayoritas normal yaitu sebanyak 85,2\%,dengan nilai $\mathrm{P}$ value=0,001, dan dari 32 responden yang baik dalam pemberian ASI status gizi balita mayoritas normal yaitu sebanyak $75 \%$, dengan nilai $\mathrm{P}$ value $=0,028$. Ada hubungan yang antara dukungan dan pemberian ASI dengan status gizi bayi 0-6 bulan di wilayah kerja Puskesmas Peukan Bada Aceh Besar Tahun 2017. Untuk itu diharapkan kepada masyarakat di Wilayah Kerja Puskesmas Tringgadeng tentang frekuensi pemberian ASI eksklusif yang benar pada bayi khususnya serta dapat menjadi bahan masukan bagi bidan untuk lebih meningkatkan mutu pelayanan asuhan kebidanan khususnya pada bayi.
\end{abstract}

\section{Kata Kunci: Dukungan Keluarga, Pemberian Asi, Status Gizi}

\begin{abstract}
Lack of nutritional intake during infancy can cause brain damage, lethargy, pain, and decreased physical growth. Nutritional status can be improved by giving optimal breastfeeding and with family support. From the data of the Peukan Bada Community Health Center in 2016, which included 27 villages, 2 toddlers (0.04\%) were malnourished, 144 children (28.8\%) were undernourished. , and 354 toddlers (70.8\%) were in good nutrition. To find out the relationship between family support and breastfeeding with 0-6 month infant nutritional status in the working area of the Aceh Besar Peukan Bada Community Health Center. This type of research is analytic with a cross-sectional approach conducted by the work area of the Aceh Besar Peukan Bada Health Center on March 15 - April 29, 2017. The number of samples in this study were 67 people with stratified random sampling technique. Data collection using questionnaires and statistical tests using chi-square. Based on the results of statistical tests, of the 27 respondents who received support from families the majority of normal nutritional status of children was $85.2 \%$, with a $P$ value $=0.001$, and of 32 respondents who were good at breastfeeding the majority of normal toddler's nutritional status was $75 \%$, with a $P$ value $=$ 0.028 . There is a relationship between support and breastfeeding with the nutritional status of infants 0-6 months in the working area of the Great Aceh Peukan Bada Health Center in 2017. For this reason it is expected that the community in the Tringgadeng Health Center working
\end{abstract}


Journal of Healthcare Technology and Medicine Vol. 3 No. 1 April 2017

Universitas Ubudiyah Indonesia

e-ISSN : 2615-109X

area on the frequency of correct exclusive breastfeeding to infants in particular and can become input material for midwives to further improve the quality of midwifery care services especially in infants.

\section{Keywords: Family Support, Breastfeeding, Nutrition Status}

\section{PENDAHULUAN}

Status gizi merupakan hasil akhir dari keseimbangan asupan gizi yang masuk ke dalam tubuh. Kebutuhan asupan gizi pada bayi berbeda dengan kebutuhan asupan gizi pada orang dewasa, baik dalam jumlah maupun proporsi. Kebutuhan asupan gizi pada bayi akan terus mengalami perubahan seiring pertumbuhannya. Pada bayi 0-6 bulan kebutuhan gizi biasanya sudah tercukupi melalui pemberian ASI secara eksklusif (Riksani, 2012).

Kekurangan asupan gizi pada masa bayi dapat menimbulkan kerusakan otak, letargi, sakit, dan penurunan pertumbuhan fisik. \Keempat keadaan ini akan berpengaruh terhadap perkembangan intelektual yang ditandai dengan lambatnya kematangan sel-sel syaraf, lambatnya gerakan motorik, kurangnya kecerdasan dan lambatnya respon sosial (Barus, 2009). Pemberian ASI eksklusif pada bayi selama 6 bulan pertama kehidupannya dapat mencegah terjadinya gizi kurang. Dimana ASI mengandung segala kebutuhan bayi seperti karbohidrat berupa laktosa, lemak yang banyak mengandung polyunsaturated fatty acid (asam lemak tak jenuh ganda), protein utama lactalbumin yang mudah dicerna, kandungan vitamin dan mineral yang mengandung rasio kalsium fosfat sebesar 2:1 yang merupakan kondisi yang ideal bagi penyerapan kalsium (Yuliarti, 2010).

Perilaku ibu dalam pemberian ASI kepada bayi merupakan salah satu faktor yang berhubungan dengan kejadian gangguan gizi pada bayi. Hasil penelitian terhadap ibu diperoleh fakta bahwa yang dapat memberikan ASI eksklusif selama 6 bulan hanya sekitar 5\% padahal 98\% ibu-ibu tersebut menyusui. Dari penelitian juga didapatkan bahwa 37,9\% dari ibu-ibu tersebut tidak pernah mendapatkan informasi dan 70,4\% pernah mendapatkan informasi tentang ASI eksklusif. Kebiasaan menyusu dapat memenuhi kebutuhan gizi bayi serta meningkatkan daya tahan tubuh sehingga membantu pertumbuhan bayi (Roesli, 2011).

Berdasarkan uraian di atas, jelas sekali di ketahui bahwa angka kejadian gizi kurang sangat tinggi di wilayah kerja Peukan Bada Aceh Besar yaitu mencapai angka 28,8\%.Oleh karena itu peneliti akan melaksanakan penelitian tentang hubungan dukungan keluarga dan pemberian asi dengan Status Gizi Bayi 0-6 Bulan di wilayah kerja Puskesmas Peukan Bada Aceh Besar. 
Journal of Healthcare Technology and Medicine Vol. 3 No. 1 April 2017

Universitas Ubudiyah Indonesia

e-ISSN : 2615-109X

\section{METODE PENELITIAN}

Jenis penelitian ini bersifat analitik dengan desain cross sectional yaitu variabel dependen dan variabel independen dilakukan pada waktu yang sama (Notoatmodjo,2010). Penelitian ini bertujuan untuk melihat Hubungan Dukungan keluarga dan Pemberian AS dengan Status Gizi Bayi 0-6 Bulan di wilayah kerja Puskesmas Peukan Bada Aceh Besar Tahun 2017.

Populasi di dalam penelitian ini adalah seluruh ibu-ibu yang mempunyai bayi berusia 0-6 bulan sebanyak 207 orang. Sampel penelitian ini adalah ibu-ibu yang mempunyai bayi umur 0-6 bulan yang berada di wilayah kerja Peukan Bada Aceh BesarKabupaten Pidie Jaya, adapun kriteria inklusifnya yaitu ibu-ibu yang mempunyai bayi umur 0-6 bulan, bayi lahir cukup bulan dengan berat badan lahir cukup .Adapun kriteria ekslusinya bayi memiliki penyakit kongenital dan penyakit kronis yang mengganggu tumbuh kembang. Dengan penetapan jumlah sampel minimum menggunakan rumus Slovin (Nursalam, 2008) sebagai berikut:

$$
\begin{aligned}
& \text { Keterangan : } \\
& \mathrm{N}=\text { Besar populasi } \\
& \mathrm{n}=\text { Besar sampel } \\
& \mathrm{d}=\text { \% kemungkinan kesalahan }(\mathrm{p}) \\
& \mathrm{n}=207 \\
& 1+207(0,1)^{2} \\
& \mathrm{n}=\underline{207} \\
& 1+207(0,01) \\
& \mathrm{n}=\underline{207} \\
& n=67,42 \text { jadi } 67 \text { orang ibu }
\end{aligned}
$$

Teknik pengambilan sampel dalam penelitian ini menggunakan teknik stratified random sampling, yaitumetode pengambilan sampel secara acak yang di lakukan pada populasi bertingkat/berstrata dengan mengambil wakil dari setiap wilayah yang terdapat dalam populasi. Hal ini di lakukan agar hasil penelitian mewakili seluruh hasil populasi yang ada karena banyaknya subjek yang berada di setiap desa tidak sama, selain itu juga mempermudah peneliti saat melakukan tehnik pengacakan cara lotlery untuk pengambilan sampel. Sehingga penentuan jumlah sampel di setiap desa dapat di hitung dengan rumus sebagai berikut: 
Journal of Healthcare Technology and Medicine Vol. 3 No. 1 April 2017

Universitas Ubudiyah Indonesia

e-ISSN : 2615-109X

$\Sigma \mathrm{Ibu}$ - ibu yang mempunyai bayi umur 0 - 6 bulan / Desa X sampel

$\Sigma$ total ibu yang mempunyai bayi umur 0 - 6 bulan

HASIL DAN PEMBAHASAN

Hubungan Dukungan Keluarga dengan Status Gizi Bayi 0-6 Bulan

Tabel 1

Hubungan Dukungan Keluarga dan Pemberian ASI dengan Status

Gizi Bayi 0-6 Bulan di wilayah kerja Puskesma Peukan Bada Aceh Besar

\begin{tabular}{|c|c|c|c|c|c|c|c|c|}
\hline \multirow{3}{*}{ No } & \multirow{3}{*}{$\begin{array}{c}\text { Dukungan } \\
\text { Keluarga }\end{array}$} & \multicolumn{4}{|c|}{ Status Gizi Balita } & \multirow{2}{*}{\multicolumn{2}{|c|}{ Total }} & \multirow{3}{*}{$\begin{array}{c}P- \\
\text { Value }\end{array}$} \\
\hline & & \multicolumn{2}{|c|}{ Normal } & \multicolumn{2}{|c|}{ Kurus } & & & \\
\hline & & f & $\%$ & $\mathbf{f}$ & $\%$ & $\mathbf{f}$ & $\%$ & \\
\hline 1. & Mendukung & 23 & 85,2 & 4 & 14,8 & 27 & 100 & \\
\hline 2. & $\begin{array}{l}\text { Tidak } \\
\text { Mendukung }\end{array}$ & 17 & 42,5 & 23 & 57,5 & 40 & 100 & 0,001 \\
\hline & Total & 40 & & 27 & & 67 & & \\
\hline
\end{tabular}

Berdasarkan tabel 1 dapat disimpulkan dari 27 responden yang mendapat dukungan dari keluarga status gizi balita mayoritas normal yaitu sebanyak 85,2\%, di bandingkan dari 40 responden yang tidak mendapat dukungan dari keluarga status gizi balitia normal yaitu sebanyak 42,7\%. Setelah dilakukan uji statistik maka diperoleh nilai $P$ value $=0,001$, yang menunjukkan adanya hubungan antara dukungan keluarga dengan status gizi bayi 0-6 bulan di wilayah kerja Puskesmas Peukan Bada Aceh BesarTahun 2016.

Hubungan Pemberian ASI dengan Status Gizi Bayi 0-6 Bulan

Tabel 2

Hubungan Pemberian ASI dengan Status Gizi Bayi 0-6 Bulan di wilayah kerja Peukan Bada Aceh Besar

\begin{tabular}{|c|c|c|c|c|c|c|c|c|}
\hline \multirow{3}{*}{ No } & \multirow{3}{*}{$\begin{array}{c}\text { Pemberian } \\
\text { ASI }\end{array}$} & \multicolumn{4}{|c|}{ Status Gizi Balita } & \multirow{2}{*}{\multicolumn{2}{|c|}{ Total }} & \multirow{3}{*}{$\begin{array}{c}P- \\
\text { Value }\end{array}$} \\
\hline & & \multicolumn{2}{|c|}{ Normal } & \multicolumn{2}{|c|}{ Kurus } & & & \\
\hline & & $\mathbf{f}$ & $\%$ & $\mathbf{f}$ & $\%$ & $\mathbf{f}$ & $\%$ & \\
\hline 1. & Baik & 24 & 75 & 8 & 25 & 32 & 100 & \\
\hline \multirow[t]{2}{*}{2.} & Kurang Baik & 16 & 45,7 & 19 & 54,3 & 35 & 100 & 0,028 \\
\hline & Total & 40 & & 27 & & 67 & & \\
\hline
\end{tabular}

Berdasarkan tabel 2 dapat disimpulkan dari 32 responden yang baik dalam pemberian ASI status gizi balita mayoritas normal yaitu sebanyak 75\%, di bandingkan dari 35 responden yang kurang baik dalam pemberian ASI status gizi balitia normal yaitu sebanyak 45,7\%. Setelah dilakukan uji statistik maka diperoleh nilai $P$ value $=0,028$, sehingga yang menunjukkan 
Journal of Healthcare Technology and Medicine Vol. 3 No. 1 April 2017

Universitas Ubudiyah Indonesia

e-ISSN : 2615-109X

adanya hubungan pemberian ASI dengan status gizi bayi 0-6 bulan wilayah kerja Puskesmas Peukan Bada Aceh Besar.

Dukungan keluarga memiliki beberapa faktor yang mempengaruhinya yaitu faktor internal yang terdiri dari tahap perkembangan yang ditentukan oleh usia sesuai dengan tahap perkembangan individu, pendidikan atau tingkat pengetahuan,faktor emosi dan spiritual.Sedangkan Faktor eketernal terdiri dari praktik di keluarga, faktor sosial ekonomi dan latar belakang budaya yang berbeda.

Hasil penelitian ini sesuai dengan teori yang dikemukakan oleh (Manuaba, 2008) (Air Susu Ibu (ASI) sangat penting bagi bayi, karena ASI merupakan makanan bergizi dan mudah dicerna. Selain itu ASI juga penting bagi perkembangan tubuh dan otaknya. Dalam ASI komposisi kandungan protein, lemak dan karbohidrat sangat mudah dicerna dalam jumlah dan mutu yang dapat diperlukan bayi. Memperhatikan perkembangan pengeluaran bayi, tiada ASI yang tiada berguna. Alam telah mempersiapkan bayi untuk tumbuh kembang hanya dengan ASI sampai umur empat bulan (ASI eksklusif), karena 4 bulan ASI memenuhi semua kebutuhan bayi.

\section{KESIMPULAN}

Berdasarkan hasil penelitian yang telah dilakukan maka penelitian dapat mengumpulkan hasil dari penelitian sebagai berikut :

1. Ada hubungan antara dukungan keluarga dengan status gizi bayi 0-6 bulan di wilayah kerja Puskesmas Peukan Bada Aceh Besardengan hasil uji statistik $p$ value $=0,001$.

2. Ada hubungan antara pemberian ASI dengan status gizi bayi 0-6 bulan di wilayah kerja Peukan Bada Aceh BesarKabupaten Pidie Jaya, dengan hasil uji statistik $p$ value $=0,028$.

\section{DAFTAR PUSTAKA}

Arikunto. S, 2010, Prosedur Penelitian Suatu Pendekatan Praktik, Jakarta: Rineka Cipta

Bahiyatun, 2009, Buku Asuhan Kebidanan Nifas Normal, Jakarta: EGC

Budiarto, E, 2012, Biostastistik Untuk Kedokteran dan Kesehatan Masyarakat, Jakarta: EGC

Pome (2012) yang berjudul "Faktor-Faktor yang berhubungan dengan Status Gizi Balita di

Wilayah Kerja UPTD Puskesmas Tanjung Agung Kecamatan Baturaja Barat Kabupaten Oku

Sediaoetama, 2006, Ilmu Gizi Untuk Mahasiswa dan Profesi, Jakarta: Dian Rakyat Supriasa, 2009, Penilaian Status Gizi, Jakarta: EGC

Virgian, B, 2012, Mengapa Menyusui Perlu Dilindungi, Artikel, Jakarta: FKUI 
Journal of Healthcare Technology and Medicine Vol. 3 No. 1 April 2017

Universitas Ubudiyah Indonesia

e-ISSN : 2615-109X

Widyastuti, 2009, Hubungan Riwayat Pemberian ASI Eksklusif dengan Status Gizi Bayi 6-12 Bulan di Provinsi NTB, Depok: FKM

Wijaya. P., W., 2013, Kapan Waktu Yang Tepat Bagi Si Kecil Diberikan Makanan Pendamping ASI, [internet] (http://www.tanyadok.com, diakses pada tanggal 2 Februari 2016)

Yuliarti, N., 2010, Keajaiban ASI Makanan Terbaik Untuk Kesehatan Kecerdasan dan Kelincahan Sikecil, Jakarta: Andi 